\title{
RECENSIES
}

\section{KENNISLEER EN DOELGERICHTHEID}

Gert Van de Vijver, Van cybernetica naar connectionisime; een epistemologische studie van doelgerichtheid. Gent, Academia Press 1991, 375 blz., 1.200 Bfr., ISBN 90382.00617

Wie meer dan gemiddeld door het weten bewogen wordt, aldus Paul Gochet in zijn voorwoord en op de flaptekst, zal door dit boek gefascineerd worden, omdat in de benadering van Gertrudis Van de Vijver de klassieke problemen uit de filosofie concrete vormen aannemen. De controversiële vraag van het gelijkstellen van mentale toestanden met toestanden in het brein bijvoorbeeld krijgt een totaal nieuwe benadering : de identiteit wordt in zeker opzicht tastbaar. Het onderwerp betreft het thema van de doelgerichtheid : zowel de gebruikte teleologische terminologie als het epistemologische probleem passeren de revue.

In dierlijke en artificiële systemen is het gebruik van teleologische terminologie allang problematisch : kunnen we veronderstellen dat dieren een vorm van bewustzijn hebben bijvoorbeeld? Volgens Immanuel Kant, aldus de auteur, moeten we voor het begrijpen van doelgerichtheid van organismen rekenschap afleggen van de paradoxale situatie waarin het geheel en de delen elkaar wederzijds bepalen. De omkering van oorzaak en effect, die altijd met teleologie verbonden werd en die mede aan de basis ligt van haar twijfelachtige reputatie, is ook nu nog onaanvaardbaar. Aangezien Kant doelgerichtheid koppelde aan subjectiviteit, kon hij aan de genoemde paradox niet ontkomen. Vandaag is er niet alleen het raadsel van de levende organisatie, maar is er bovendien de cybernetische context : de constructie van doelgerichte machines. Hier stelt men de vraag naar de reduceerbaarheid van doelgerichtheid : is het mogelijk om de vormen en gedragingen die we doelgericht noemen, op een vernieuwde mechanistische wijze te benaderen ? Wat zijn de gevolgen van deze reductie? Hoe verhoudt zich daarbinnen de verklaring van doelgerichtheid tot de betekenis van doelgerichtheid ? (blz. 2)

Deze zogenaamde harde kern van de eerste cybemetica mondt uit in positiebepalingen die meer verband houden met de vraag van de betekenis van doelgerichtheid. Hier is het centrale probleem dat van de autonomie geworden. Volgens deze tweede cybernetica varieert betekenis overeenkomstig het perspectief van de observator : alleen interactie is nog mogelijk. Het epistemologische belang van deze interpretatie wordt vooral vertolkt in het constructivisme en men kan zich afvragen of en hoe deze filosofie een 'meer wetenschappelijke' (blz. 3) verankering krijgt in het neo-connectionisme.

Ook in het neo-connectionisme kan men een tweedeling aantreffen : in het verlengde van de eerste cybemetica dat van de zogenaamde Parallel Distributed Processing waarin 
de discussie veeleer over emergentie en naturalisme handelt, en dat van Henri Atlan en Francisco Varela dat meer aansluit bij de tweede cybernetica en dat de vraag van de doelgerichtheid in abstracto uitwerkt op basis van de emergentie als zelf-organiserend proces van betekenis in de netwerken. De auteur behandelt ter ondersteuning van de genoemde tweedeling in cybernetica en connectionisme het naturalisme en het constructivisme.

Om de epistemologische draagwijdte van doelgerichtheid in de cybemetica te begrijpen, krijgt de lezer eerst de nodige terminologische uitleg : hoe verhoudt het concept zich tot doelmatigheid en doeltreffendheid, in hoeverre is het verwant met functionaliteit ? Wat is de relatie tussen causale en teleologische verklaringen? Hoe zit het met de verhouding tussen identificatie en verklaring, tussen teleologische reductie en causaal mechanicisme?

Aangezien dit bock zich beperkt tot de causale analysen van doelgerichtheid (blz. 37), onderscheidt de auteur twee grote benaderingen : het externalisme en het internalisme, met daarbij een analyse van de problemen die op een uitgesproken manier met de extreme benaderingen zijn verbonden. Jammer dat Van de Vijver niet ingaat op de vraag van de noodzaak aan een kernconcept dat zou verwijzen naar de mentale invulling van de doelgerichtheid en van waaruit, zoals ze zelf schrijft, op een metaforische manier de doelgerichtheid in artificiële en eenvoudige naturlijke systemen zou moeten worden begrepen (blz. 39). Daar zou de gemiddelde lezer zich wellicht ook in kunnen terugvinden.

In het tweede deel van haar boek gaat de auteur in op de klemtonen die aanwezig waren in de Macy-conferentics uit de jaren vijftig, cybernetische conferenties die veel belang hechtten aan wiskundige modellen, aan de geesteswetenschappen en aan interdisciplinariteit. Toen al werden twee posities onderscheiden : die van ingenieur, voor wie de technologie in het cybernetische programma doorweegt, en die waarbij men, vanuit de studie van de neurologische en biologische wortels van kennis, een model van cognitieve en doelgerichte verschijnselen via de machine nastreeft.

Gezien de veelheid aan mogelijke invalshoeken om via de analyse van de doelgerichtheid een juister beeld te krijgen van de eerste en de tweede cybemetica, vertrekt G. Van de Vijver van enkele funderende teksten : 'Behavior, Purpose, and Teleology' van A. Rosenblueth en anderen en 'A Logical Calculus of the Ideas Immanent in Nervous Activity' van W.S. McCulloch en W. Pitts. Tenslotte situeert ze de betekenis van de automatentheorie van Von Neumann. Deze laatste was diegene die van bij het begin doorzag welke de inzet van de computers was, en "daarmee kondigt hij als eerste op een expliciete manier de thema's aan die later in de zogenaamde complexiteitstheorieën en de theorieèn van de auto-organisatie aan bed komen" (blz. 128).

Deze auto-organisatie wordt diepgaand geanalyseerd en op twee manieren vertolkt : een perspectieve en een heuristische invulling. Deze laatste vindt onder meer vertegenwoordiger in H. Maturana en F.J. Varela, wier biologie van de cognitie op boeiende wijze wordt samengevat met aandacht voor het zogenaamde probleem van de structurele koppeling : "Hoe is het mogelijk dat een organisme een zulkdanige structuur bezit dat het zich doeltreffend gedraagt in een omgeving ?" (blz. 192) en met aandacht voor de plaats van de taal en de observator. Jammer opnieuw dat de auteur zich niet waagt aan conceptuele verfijningen binnen het domein van de biologie en de evolutietheorie. Ze gaat wel uitvoerig 
in op de vraag of er ook in de wetenschappelijke disciplines enig nut ligt in de constructivistische theorie. Voor Van de Vijver is constructivisme "de algemene filosofische positie die enerzijds de observator-gebondenheid van elke kennis uitdrukt en die anderzijds suggereert toch tot een nieuw soort "objectiviteit' te komen" (blz. 209). De epistemologische gevolgen verbonden met het constructivisme leveren uiteindelijk maar vier staakwoorden op : onvolledigheid, uniciteit, actie en individualiteit. Mager dus.

In het derde en laatste deel van haar studie bespreekt Van de Vijver enkele voorlopers van het huidige connectionisme (McCulloch, Rosenblatt, Kaufmann, Von Neumann) om dan in te gaan op de indelingen en soorten netwerken in het neoconnectionisme zoals dat vooral in de Verenigde Staten opgang maakt, namelijk "de studie van massief parallelle architecturen voor artificiële intelligentie" (blz. 243). Twee vormen van connectionisme komen ter sprake : de Hopfield- of Hinton-netwerken die ontwikkeld werden vanuit de thermodysamica en de statistische fysica, en de cellulaire automatennetwerken die behandeld worden op basis van de theorie van H. Atlan en deze van F. Varela. De auteur pleit uiteindelijk voor een tweedeling in het huidige connectionisme : de technologisch georiënteerde en de biologisch-epistemologisch georiënteerde benadering. Orn de verschillen tussen beide te schetsen, wordt omstandig ingegaan op de rol die de emergentie in het naturalisme en in het neo-connectionisme speelt. Met het oog op het connectionisme moet met Ernest Nagel onthouden worden dat "de emergentie als verklarende categorie verwijst naar de logische onmogelijkheid om een voorspelling te maken : het is onmogelijk om de beschrijving van cen emergente eigenschap af te leiden van de beschrijving van eigenschappen van de lagere niveaus" (blz. 312). Tenslotte komt de discussie met betrekking tot semantische inhoud aan bod, omdat dit twistpunt een bijzondere betekenis heeft voor de relatie tussen doelgerichtheid en intentionaliteit, en de mogelijkheid van vergissing, die ontstaat als gevolg van de geschiedenis, en een noodzakelijke voorwarde is opdat men met de doelgerichtheid te maken zou hebben.

In haar conclusies pleit Van de Vijver op het niveau van de keuze van een adequate theorie voor een 'multiplisme', omdat empirisch gesproken niets ons toelaat te kiezen voor een bepaalde theorie en niet voor een andere. Men kan zich afvragen wat dan de specifieke plaats van de epistemologie en van de filosofie nog is. "Het is de rol van de filosofie om te spreken over datgene wat niet geformaliseerd kan worden, om een natuurlijke taal te gebruiken, met metaforen, analogieln, met vaagheid, zonder in een extreem subjectivisme te vervallen" (blz. 343). De epistemologie moet de 'pseudo-concepten' ondervragen, waartoe ook de doelgerichtheid behoort. Een onwetendheid over de totaliteit van de determinaties maakt volgens $V$ an de Vijver deel uit van wat we een natuurlijke organisatie noemen. Die onwetendheid is volgens haar - en hierin noemt ze zich constructivist equivalent met de reěle indeterminatie in de natuur : "Er bestaat niets wat ons toelaat om te doen alsof die onwetendheid niet bestaat". We zullen het na de lectuur van dit magistrale boek graag onthouden... 